\title{
Computational modeling of flat slabs: Influence of ribs and flexural reinforcement on shear strength
}

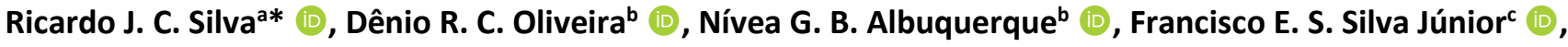 \\ Paulo V. P. Sacramento ${ }^{b}$ (D) \\ a Faculdade de Engenharia Civil, Universidade Estadual Vale do Acaraú - UVA, Rua Dr. Guarany 317, Sobral-CE, Brasil. Email: \\ ricardo.carvalho222@gmail.com \\ b Faculdade de Engenharia Civil, Universidade Federal do Pará - UFPA, Rua Augusto Corrêa s/n, Belém-PA, Brasil. Email: denio@ufpa.br, \\ nivea@ufpa.br, pvictor.eng@gmail.com \\ c Faculdade de Engenharia Civil, Universidade Estadual Vale do Acaraú - UVA, Rua Dr. Guarany 317, Sobral-CE, Brasil. Email: \\ jrsuri@outlook.com
}

* Corresponding author

http://dx.doi.org/10.1590/1679-78256128

\begin{abstract}
A greater number of structures are being built with flat reinforced concrete slabs because they offer several advantages. However, many designers are still unsure about the type of slab that has the best structura performance and which building codes provide the best strength estimates. This study presents nonlinear computer simulations of 16 flat reinforced concrete slabs under symmetrical punching: 4 solid slabs, 4 waffle slabs with wide beams, and 8 waffle slabs with different numbers of ribs supported in the solid area of the slab. Geometric longitudinal reinforcement ratios ranged from $0.45 \%$ to $1.97 \%$. The results showed that solid and beamed slabs are more resistant, and normative estimates overestimate their strengths, while the opposite outcome was found for waffle slabs, whose estimates provided in the codes were rather conservative. The most accurate code was EC2, followed by ACl 318 and NBR 6118.
\end{abstract}

\section{Keywords}

Punching, Flat waffle slab, Wide beam

\section{Graphical Abstract}

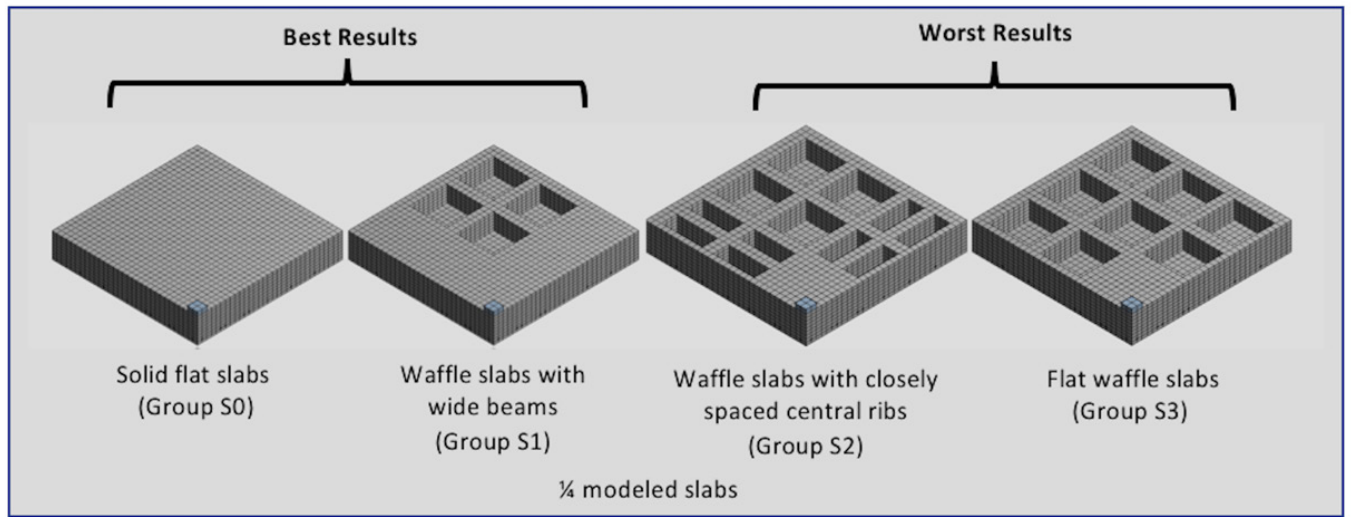




\section{INTRODUCTION}

Punching shear is a type of brittle failure that occurs in slabs as a result of the application of a concentrated force, such as the reaction of the column on the slab, for example. This failure may lead to an unplanned redistribution of efforts and cause a domino effect of punching failure, known as progressive collapse. Kinnunen \& Nylander (1960) proposed the first relevant mechanical model for punching shear after analyzing experimental tests with 61 circular slabs (without shear reinforcement) supported on circular columns. They reported that, with increased loadings, radial cracks appeared on the top face of the slab, followed by a circumferential crack that formed at the top of the punching cone. Together with radial cracks, they outlined "slices" in a slab. These "slices" in the slab were deformed, and rotated around a center, causing the area to be crushed on the bottom face of the slab.

Important experimental works, e.g., those of Regan $(1981,1986)$ and Regan \& Bræstrup (1985), provided relevant insights to the development of punching shear research. One of the most important findings that influenced the current normative equations was that when the reinforcement ratio of a slab is increased, its punching shear strength also increases. Subsequently, Muttoni (2008) introduced the Critical Shear Crack Theory (CSCT), which was based on the shear crack along the slab thickness, cutting the compression strut that transmits load to column. Thus, he demonstrated that the punching strength curve was inversely proportional to the slab rotation curve. Lastly, Muttoni created an equation for the load-rotation ratio to estimate a slab punching resistance value. Based on the work of Muttoni (2008), Bompa \& Onet (2016) proposed a simplified model for struts and ties for estimation of slab punching strength without the need to calculate rotation.

The point is that, in general, building codes and standards establish formulas that estimate punching strength for solid flat slabs, based on the above-mentioned theories, but they hardly address waffle slabs. ACl $318(\mathrm{ACl}, 2019)$, Eurocode 2 (EC2) (CEN, 2004) and NBR 6118 (ABNT, 2014) propose some calculations to estimate rib shear failure and recommend the use of the same formulas for punching shear. However, waffle slabs were tested in recent experimental studies, such as those of Al-Bayati et al. (2015, 2018), Arunkumar et al. (2018) and Sacramento et al. (2018). It was found that strength was reduced in some of the slabs when the punching cone reached the rib region. In other words, to avoid a reduction in slab strength, the punching cone must not exceed the perimeter of the solid region of waffle flat slabs. If it does, the normative estimates must be adjusted to enable a safer structural design.

This problem has motivated this computational study, whose main objective was to investigate and compare the structural behavior of each type of slab using computational modeling, as well as check the influence of reinforcement ratio and slab rotation on ultimate strength and distribution of maximum and minimum principal stresses. Experimental tests were simulated on 4 solid flat slabs, 4 waffle slabs with wide beams, 4 waffle flat slabs with closely spaced central ribs and 4 waffle flat slabs with evenly spaced ribs. The slabs in each group had longitudinal reinforcement ratios of $0.45 \%, 0.90 \%$, $1.41 \%$ and $1.97 \%$, respectively. In addition, the estimates of building codes $\mathrm{ACl} 318$ (ACl, 2019), Eurocode 2 (EC2) (CEN, 2004) and NBR 6118 (ABNT, 2014) were evaluated for punching shear and shear strengths of slab ribs. Although this is not a totally new subject, the outcomes of the present research can offer relevant scientific and design-related contributions with specific provisions for waffle flat slabs in case of future code amendments.

\section{NORMATIVE RECOMMENDATIONS}

\section{$2.1 \mathrm{ACl} 318(\mathrm{ACl}, 2019)$}

$\mathrm{ACl} 318$ estimates punching shear $\left(V_{A C l, p}\right)$ for slabs without shear reinforcement using the lowest value provided by equations 1,2 and 3 , where $f_{c}$ the compressive strength of concrete limited to $70 \mathrm{MPa}, 6$ is the ratio between the largest and smallest column dimensions, $\lambda$ is the modification factor that takes on a value equal to 1.0 for normalweight concrete or between 0.75 and 0.85 for lightweight concrete, $\lambda_{s}$ is the size effect factor which is calculated by $\lambda_{s}=\sqrt{2 /(1+0.004 \cdot d)} \leq 1, \alpha_{s}$ is the constant that takes on a value equal to 40 for internal columns or 30 for edge column or 20 for corner columns, $d$ is the effective depth of the section and $u_{1}$ is the control perimeter according to $\mathrm{ACl} 318$ (Figure 1). For waffle slabs, ACl 318 recommends that ribs should have a minimum width $\left(b_{w}\right)$ of $100 \mathrm{~mm}$, height $\left(h_{b}\right)$ no more than 3.5 times the minimum rib width, and maximum spacing between rib faces $(s)$ of $750 \mathrm{~mm}$. Topping slab thickness $\left(h_{f}\right)$ must be at least $37.5 \mathrm{~mm}$ and equivalent to the $s / 12$ ratio at most (Figure 1 ). For analysis of the ribs without transversal reinforcement, $\mathrm{ACl} 318$ estimates shear strength through Equation 4, where $\lambda$ is the modification factor, $b_{w}$ is rib width and $d$ is the effective depth of the section.

$V_{A C I, p}=0.33 \cdot \lambda_{s} \cdot \lambda \cdot \sqrt{f_{c}} \cdot u_{1} \cdot d$ 


$$
\begin{aligned}
& V_{A C I, p}=\left(0.17+\frac{0.33}{\beta}\right) \cdot \lambda_{s} \cdot \lambda \cdot \sqrt{f_{c}} \cdot u_{1} \cdot d \\
& V_{A C I, p}=\left(0.17+\frac{0.083 \cdot \alpha_{s} \cdot d}{u_{1}}\right) \cdot \lambda_{s} \cdot \lambda \cdot \sqrt{f_{c}} \cdot u_{1} \cdot d \\
& V_{A C I, R}=0.083 \cdot \lambda \cdot \sqrt{f_{c}} \cdot b_{w} \cdot d
\end{aligned}
$$

\subsection{Eurocode 2 (EC2) (CEN, 2004)}

$E C 2$ estimates punching shear load $\left(V_{E C, p}\right)$ for slabs without shear reinforcement through Equation 5 . In this equation, $\rho_{l}$ is the longitudinal reinforcement ratio and it is not greater than $0.02, \xi=(1+\sqrt{200 / d}) \leq 2.0$ and $u_{1}$ is the control perimeter according to EC2 (Figure 1). For waffle slabs, EC2 states that the topping slab and the ribs do not need to be analyzed separately when there is sufficient torsional stiffness between these two elements. Also, waffle slabs can be analyzed as if they were solid slabs. However, this condition will only be acceptable if spacing between the faces of the ribs $(s)$ does not exceed $1500 \mathrm{~mm}$, if rib height $(H)$ is no greater than 4 times its width $\left(b_{w}\right)$ and if topping slab height $\left(h_{f}\right)$ is at least the greater of these two factors: $(s / 10)$ or $(50 \mathrm{~mm})$ (Figure 1). To analyze the ribs without transversal reinforcement, EC2 estimates shear strength with Equation 6.

$$
\begin{aligned}
& V_{E C, p}=0.18 \cdot \xi \cdot\left(100 \cdot \rho_{l} \cdot f_{c}\right)^{\frac{1}{3}} \cdot u_{1} \cdot d \\
& V_{E C, R}=0.18 \cdot \xi \cdot\left(100 \cdot \rho_{l} \cdot f_{c}\right)^{\frac{1}{3}} \cdot b_{w} \cdot d
\end{aligned}
$$

\subsection{NBR 6118 (ABNT, 2014)}

NBR 6118 estimates punching shear load $\left(V_{N B R, p}\right)$ for slabs without shear reinforcement according to the Equation 7. Here, $\xi=(1+\sqrt{200 / d})$ and $u_{1}$ is the control perimeter according to NBR 6118 (Figure 1). It should be noted that NBR 6118 does not limit the size effect $(\xi)$ nor the longitudinal reinforcement ratio $\left(\rho_{l}\right)$, unlike EC2.

$V_{N B R, p}=0.18 \cdot \xi \cdot\left(100 \cdot \rho_{l} \cdot f_{c}\right)^{\frac{1}{3}} \cdot u_{1} \cdot d$

For waffle slabs, NBR 6118 recommends that the ribs should have a minimum width $\left(b_{w}\right)$ of $50 \mathrm{~mm}$ and if they have compression reinforcement, minimum width $\left(b_{w}\right)$ becomes $80 \mathrm{~mm}$ (Figure 1). Topping slab thickness must be at least $50 \mathrm{~mm}$ when there is conduit wiring of $\Phi 10 \mathrm{~mm}$ or at least $(40 \mathrm{~mm}+\Phi)$ inside the slabs has a diameter greater than $\Phi 10 \mathrm{~mm}$ or at least $(40 \mathrm{~mm}+2 \Phi)$ when there is a conduit crossover inside the slabs. If the spacing between the axes of the ribs is less than or equal to $650 \mathrm{~mm}$, there is no need to either test the topping slab as an independent slab or to check rib shear strength. When the spacing between the axes of the ribs is between $650 \mathrm{~mm}$ and $1100 \mathrm{~mm}$, bending of the topping slab must be checked and the ribs must be dimensioned as beams, and calculations have to be made to check shear strength. However, when the spacing between the axes of the ribs is up to $900 \mathrm{~mm}$ and the average rib width is greater than $120 \mathrm{~mm}$, there is no need to check the topping slab. In case the spacing between axes is greater than $1100 \mathrm{~mm}$, the topping slab must be calculated as a solid slab, supported on the beam grid, while respecting the minimum thickness limits. To analyze the ribs without transversal reinforcement, NBR 6118 recommends equations 8 to 10 , where $\tau_{R}=0.05\left(f_{c}\right)^{2 / 3}, k=|1.6-d|$, with $d$ in meters and $\rho_{1}=A_{s 1} /\left(b_{w} d\right) \leq 0.02$, where $A_{s 1}$ is the longitudinal reinforcement in the rib and $b_{w}$ is the minimum width of the section along the effective depth $d$.

1. (a) Calculation to check diagonal compressive strength:

$V_{N B R, C D}=0.27 \cdot \alpha_{v 1} \cdot f_{c} \cdot b_{w} \cdot d$

$\alpha_{v 1}=1-f_{c} / 250$

2. (b) Calculation to check diagonal tensile strength:

$V_{N B R, T D}=\left[\tau_{R} \cdot k \cdot\left(1.2+40 \rho_{1}\right)\right] \cdot b_{w} \cdot d$ 


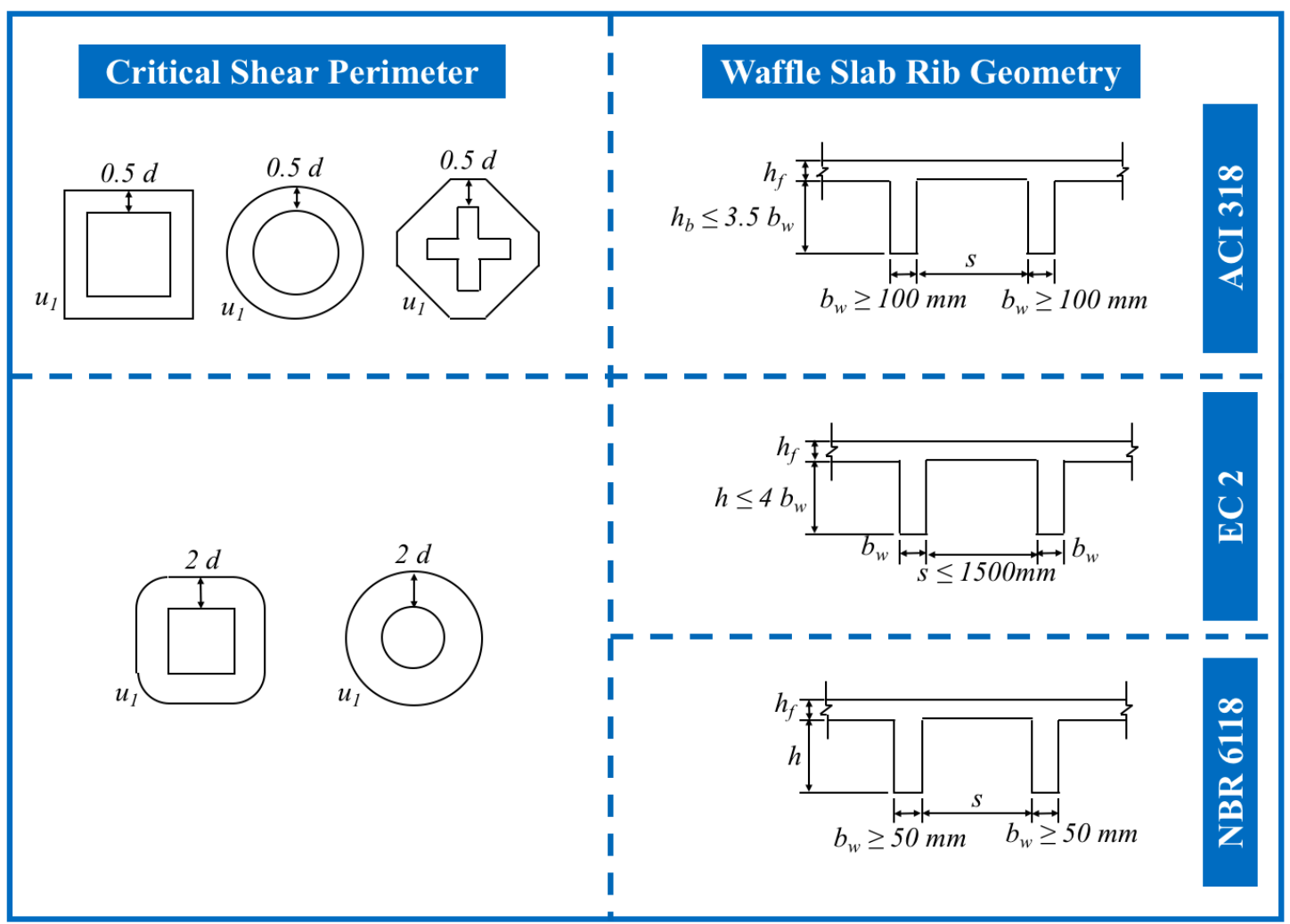

Figure 1 - Control perimeter and rib geometry. Source: Authors' own data

\section{METHOD}

\subsection{SLAB PROPERTIES}

This research used the computer software Ansys Workbench to perform non-linear analyses on 16 flat reinforced concrete slabs, divided into 4 groups (SO, S1, S2 and S3) (Figure 2). Group S0 is composed of 4 solid flat slabs (S1S0, S2SO, S3SO and S4SO) with reinforcement rates of $0.45 \%, 0.90 \%, 1.41 \%$ and $1.97 \%$, respectively. Group S1 is composed of 4 waffle slabs with wide beams (S1S1, S2S1, S3S1 and S4S1) with reinforcement ratios of $0.45 \%, 0.90 \%, 1.41 \%$ and $1.97 \%$, respectively. Group S2 is composed of 4 flat waffle slabs with closely spaced central ribs (S1S2, S2S2, S3S2 and S4S2) with reinforcement ratios of $0.45 \%, 0.90 \%, 1.41 \%$ and $1.97 \%$, respectively. Group S3 group is composed of 4 flat waffle slabs (S1S3, S2S3, S3S3 and S4S3) with reinforcement ratios of $0.45 \%, 0.90 \%, 1.41 \%$ and $1.97 \%$, respectively. The 16 slabs have height (h) of $150 \mathrm{~mm}$, effective depth (d) of $133 \mathrm{~mm}$, support dimensions (c x c) of $120 \mathrm{~mm} \times 120 \mathrm{~mm}$, average concrete compression strength $\left(f_{c}\right)$ of $40 \mathrm{MPa}$, average concrete tensile strength $\left(\mathrm{f}_{\mathrm{t}}\right)$ of $3.5 \mathrm{MPa}$ and steel yield strength $\left(\mathrm{f}_{\mathrm{y}}\right)$ of $500 \mathrm{MPa}$. Table 1 shows the arrangement of the reinforcements in the study slabs.

The method used in Ansys (2013a) (2013b) was incremental, with step-by-step application of load/deformation, through substeps up to slab failure. In this way, a possible experimental test was simulated, using the dimensions of the slabs on a 1:2 scale to represent the region of negative bending moment of a slab with a span of approximately 7600 mm, slab thickness of $300 \mathrm{~mm}$ and column dimensions of $250 \mathrm{~mm} \times 250 \mathrm{~mm}$. It should be noted that, in this research, there was no intention to correlate the study slabs with a full-scale prototype, through quantitative research. This research is merely qualitative; it compared slabs with solid areas in different dimensions, in order to estimate percentages of gains and losses of strength. 
Group S0

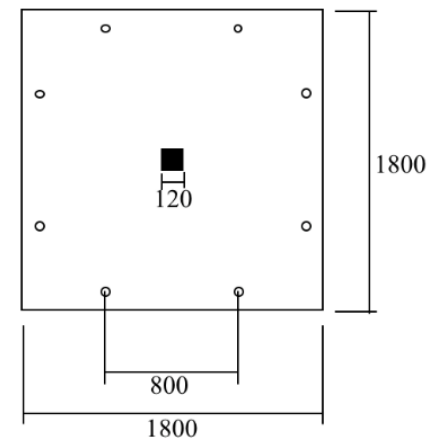

Group S2

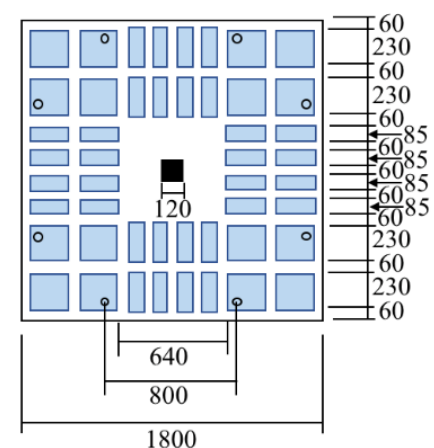

Group S1

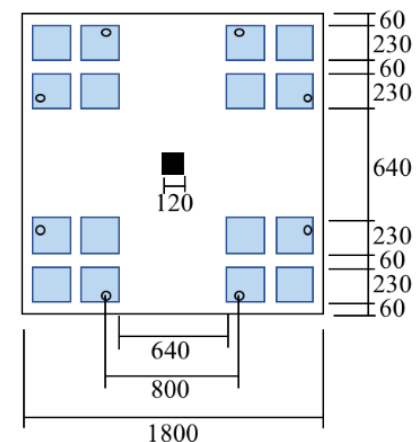

Group S3

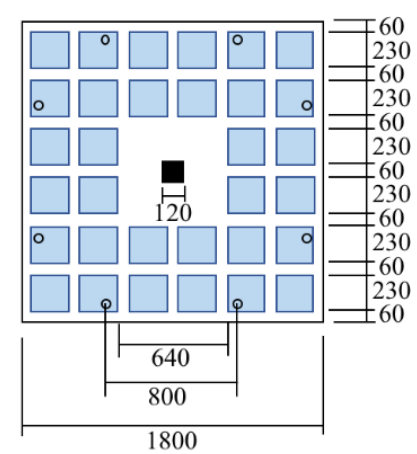

Figure 2 - Slabs of groups S0, S1, S2 and S3. Source: Authors' own data

Table 1 Data on the study slabs

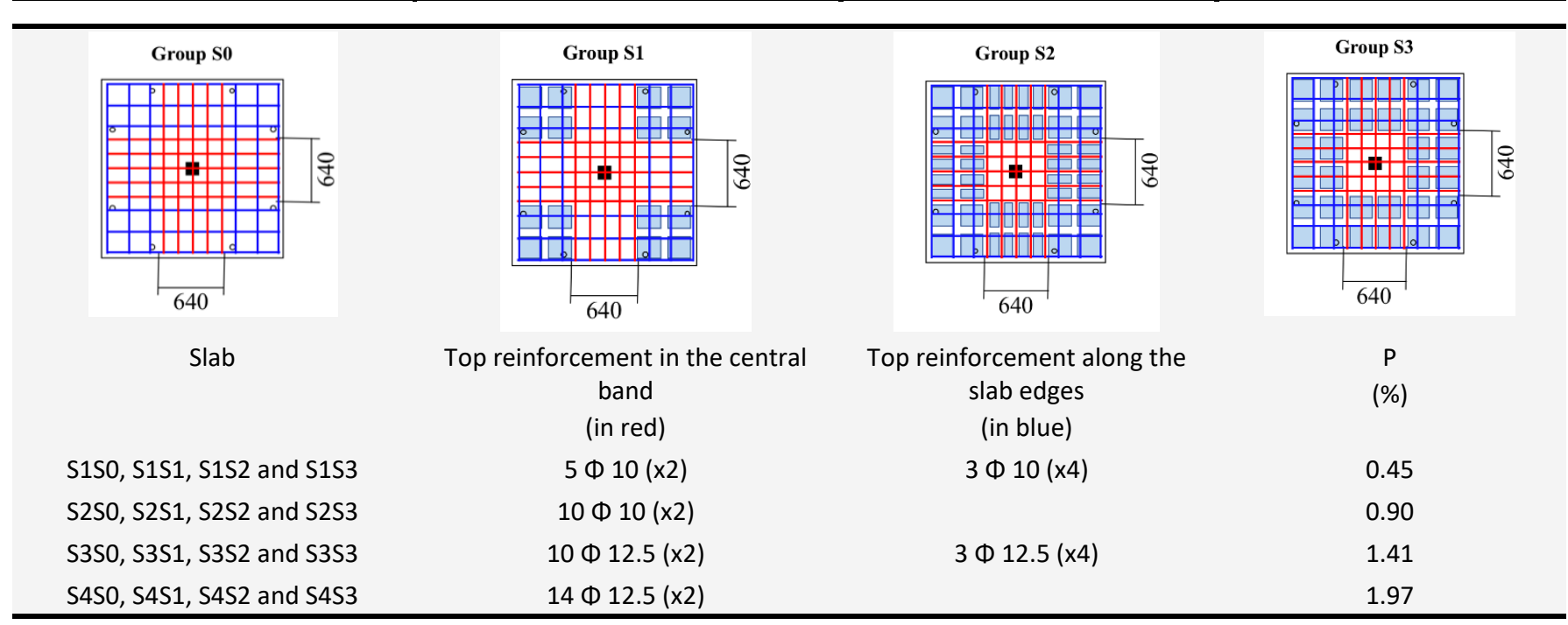

\subsection{COMPUTATIONAL MODELING}

Modeling for the slabs was performed on the platform Workbench Ansys, and a nonlinear and static analysis was defined. The Solid65 and Link180 elements were used for the concrete and the reinforcements, respectively. The constitutive model of Ansys for concrete is the concrete model, which uses the constitutive equations of Willam \& Warnke (1974), with five parameters for failure. This model predicts failure of brittle materials, and it can work with cracking (tensile damage) and crushing (compression damage) as failure modes, as shown in Figure 3. This computer software was selected because it is widely used in nonlinear analysis of structures, has a user-friendly interface, and provides satisfactory responses when they are compared to experimental results. 


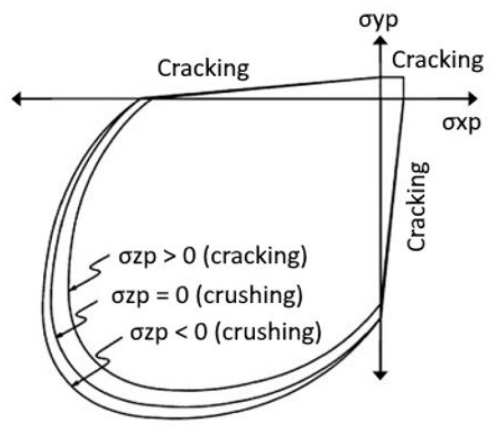

(a) Compression

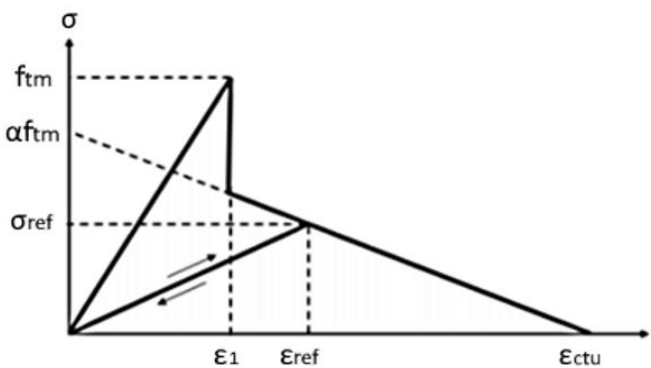

(b) Tension

Figura 3 -Concrete constitutive model. Source: Ansys (2013b)

For steel, a perfect bilinear elastoplastic model was adopted, with tangent modulus ( $\mathrm{E}_{\mathrm{T}}$ ) equal to $0 \mathrm{MPa}$, considering that the reinforcements only have axial stress-strength. Poisson's ratio $\left(v_{s}\right)$ was 0.3 for steel, and bond strength between reinforcement and concrete was considered to be perfect. The Solid185 element was defined for load application and support points, using the same material of the reinforcements, but without the nonlinearity properties.

For concrete, estimates were made for the initial tangent elastic modulus $\left(E_{c i}\right)$, of the FIB (2011), which was equal to $34.1 \mathrm{GPa}$. Poisson's ratio of concrete $\left(v_{c}\right)$ and the shear transfer coefficient was 0.3 for open cracks and 1.0 for closed cracks. The stress-strain graph for compressed concrete was defined as recommended by the FIB (Equation 11) and shown in Figure 4, with maximum stress achieved reached at $2.3 \%$ strain. After maximum stress was achieved, stress was considered to be constant until reaching failure deformation of $3.5 \%$, since Ansys does not allow a negative inclination in this graph.

$\sigma_{c}=f_{c}\left[1-\left(1-\frac{\varepsilon_{c}}{\varepsilon_{c 2}}\right)^{n}\right]$

where:

$\sigma_{c}:$ compressive strength of concrete;

$f_{c}$ : average compressive strength of concrete;

$\varepsilon_{c}$ : concrete strain;

$\varepsilon_{c 2}$ : concrete strain at the beginning of the yield plateau;

$n$ : exponent ( 2 for concretes under $50 \mathrm{MPa}$ ).

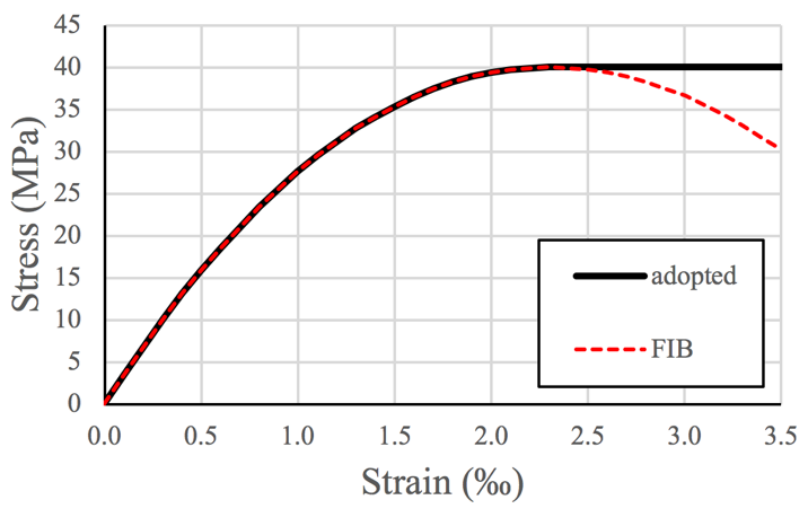

Figure 4 -Stress-strain graph for compressed concrete. Source: Authors' own data

To reduce the computational effort in the analyses, only a quarter of the slabs were modeled and regions of symmetry were defined in the $X$ and $Z$ directions. The finite element mesh was divided into 31 elements in the $X$ and $Z$ directions, and divided into 9 elements in the $Y$ direction. Thus, a mesh only with hexahedral elements was generated. In addition, the reinforcement nodes could be matched with the concrete element nodes; this is a condition required for analyses with the Solid65 element (according to Silva et al. (2019)). Figure 5 shows the model of the slabs. The analyses used a convergence criterion based on displacement, where tolerance was set at $1 \%$, and the complete Newton-Raphson 
method was adopted. Loading was applied in a single loading step and 100 substeps. Loads were applied to the slabs as a small displacement from top to bottom on the upper face of the load application points. Supportive reactions were defined as zero displacements in the $Y$ direction on the bottom face of the column. The contact regions between all solids were defined with the bonded contact and the Pure Penalty formulation. Slab failure was considered to occur when the software returned an error of magnitude and the simulations were interrupted, indicating that the structure had reached its ultimate strength. Failure could also be identified through the vertical load-displacement curves of the slabs over the load application points.
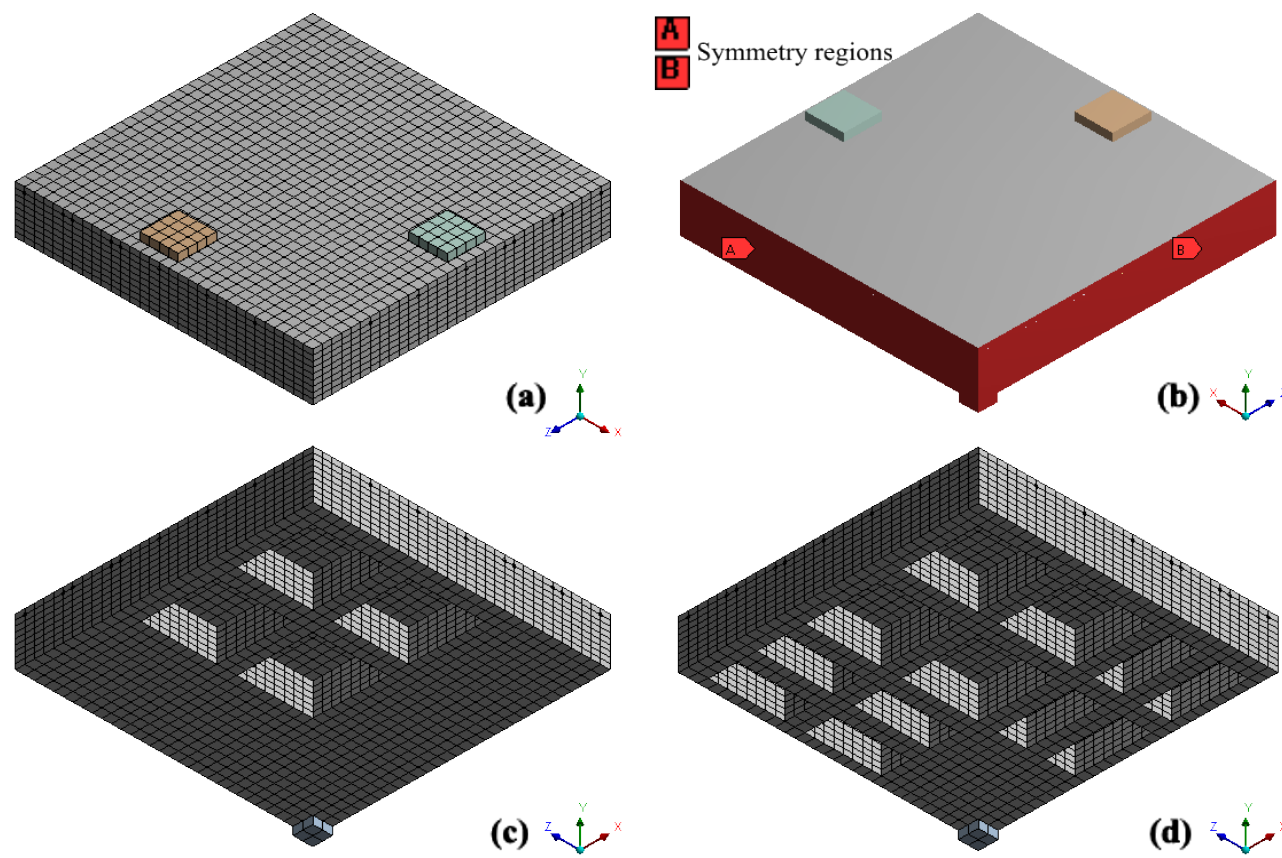

Figure 5 - Model for the slabs (a), symmetry regions (b), detail of the ribs of slab S2S1 (c), detail of the ribs of slab S2S3. Source: Authors' own data

\subsection{COMPUTATIONAL MODEL VALIDATION}

The waffle flat slab L3 tested by Albuquerque (2009) and the solid flat slab tested by Ramos (2003) were simulated with Ansys and the computational results were compared to their experimental results, in order to validate the computational analyzes performed in this article. The Albuquerque slab L3 had a dimension of $1800 \mathrm{~mm} \times 1800 \mathrm{~mm}$ with $150 \mathrm{~mm}$ thickness, with ribs $50 \mathrm{~mm}$ width $250 \mathrm{~mm}$ axis to axis spacement, supported on a stell plate measuring $120 \mathrm{~mm} \times 120 \mathrm{~mm} \times 50 \mathrm{~mm}$, and the Ramos slab AR2 (2003) had dimension of $2300 \mathrm{~mm} \times 2300 \mathrm{~mm}$ sides and $100 \mathrm{~mm}$ thickness. The distribution of reinforcement at the top of the slabs is shown in Figure 6 . The testing scheme of the slabs L3 and AR2 is shown in Figure 7. The experimental and computational displacements of the slabs were measured at point $B$ in relation to point $A$ and are shown in Figure 8. L3 and AR2 slabs failed by punching shear with loads of $150.5 \mathrm{kN}$ and $258 \mathrm{kN}$, respectively, and in the computational simutation both slabs also failed by punching shear with loads of $145.0 \mathrm{kN}$ and $268 \mathrm{kN}$, respectively. The Table 2 presents the data and experimental results of the waffle flat slab L3 from Albuquerque and the solid flat slab AR2 from Ramos that were used to compare with the numerical results and with the normative estimates. Table 2 showed accurate results when comparing the experimental and computational failure loads. The normative results were conservative in relation to shear in the ribs. Figure 8 (a) and (b) show the good approximation for experimental and computational load vs displacement curves, and Figure 9 (a), (b), (c) and (d) highlight the strains and the maximum principal stresses that raise radial and circumferential cracks before the punching shear failure cone shaping, suggesting reasonable agreement with the experimental results. It is observed that displacements, strains and principal tensile stresses of AR2 slab are greater than those of L3 slab because AR2 slab is more flexible than L3 slab, and the small solid area of the Albuquerque L3 waffle flat slab reduced its resistance considerably. 

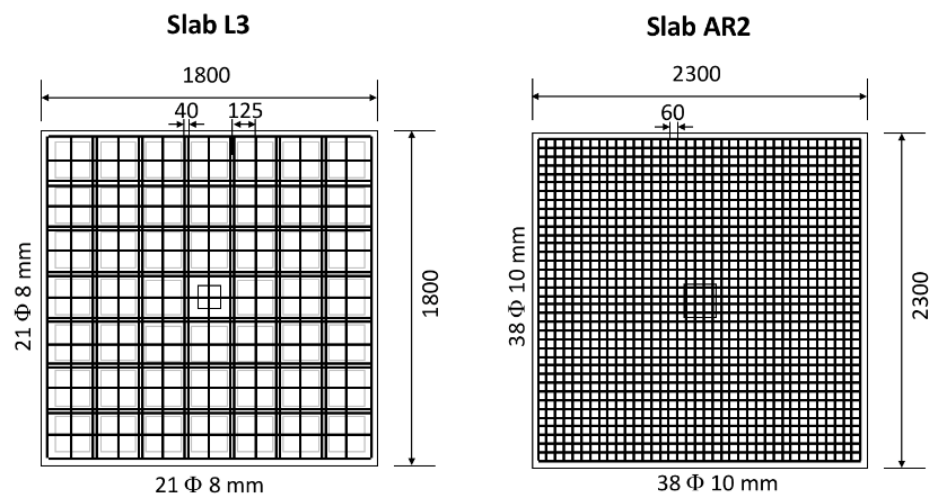

Figure 6 - Reinforcement on the top of the slabs. Source: Albuquerque (2009) and Ramos (2003)

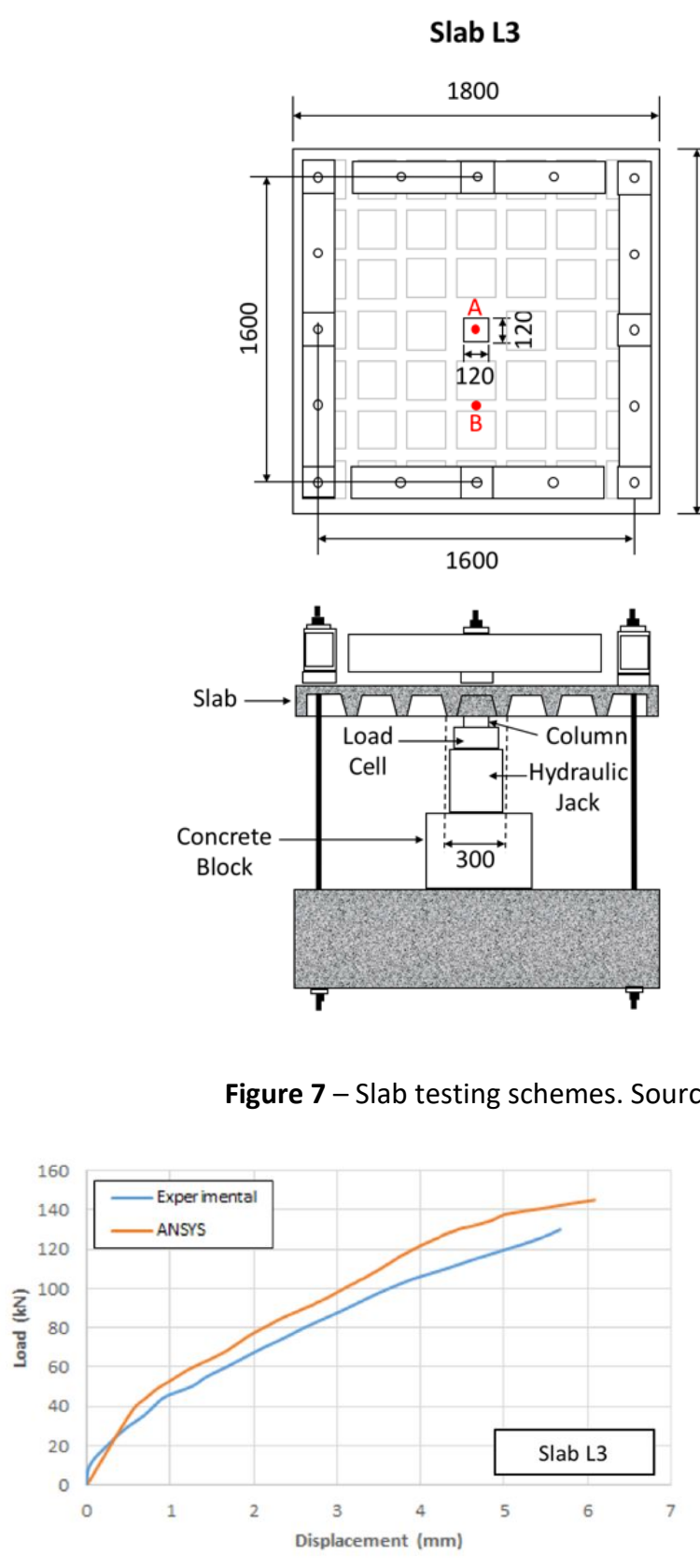

(a) Load vs displacement curves for Albuquerque (2009)

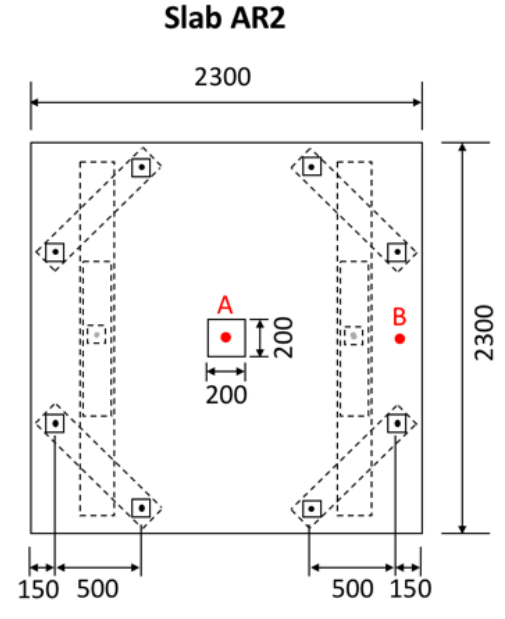

Slab

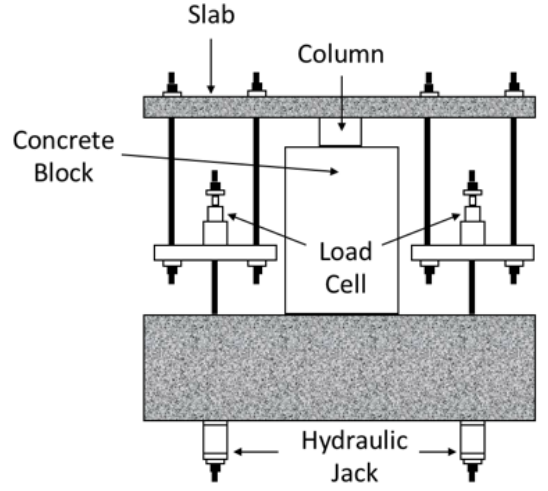

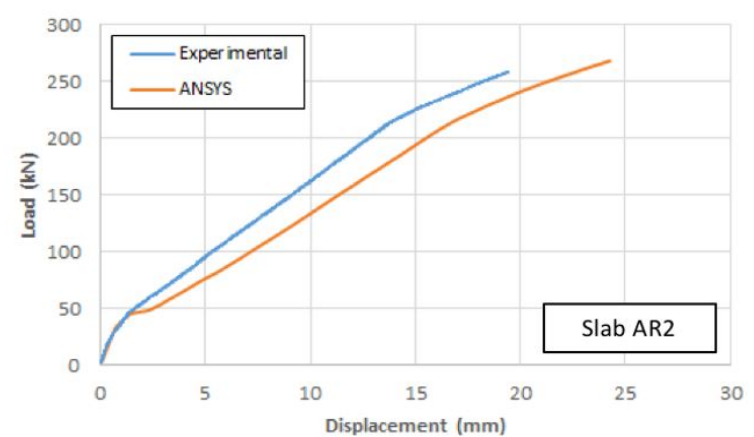

(b) Load vs displacement curves for Ramos (2003)

Figure 8 - Experimental and computational curves load vs displacement. Source: Authors, Albuquerque (2009) and Ramos (2003) 
Table 2 Results for L3 and AR2 slabs

\begin{tabular}{|c|c|c|c|c|c|c|c|c|c|c|c|}
\hline Slab & $\begin{array}{c}c \\
(\mathrm{~mm})\end{array}$ & $\begin{array}{c}\mathrm{h} \\
(\mathrm{mm})\end{array}$ & $\begin{array}{c}d \\
(\mathrm{~mm})\end{array}$ & $\begin{array}{c}\rho \\
(\%)\end{array}$ & $\begin{array}{c}\mathbf{f}_{\mathrm{c}} \\
(\mathrm{MPa})\end{array}$ & $\begin{array}{c}f_{y} \\
(\mathrm{MPa})\end{array}$ & $\mathrm{V}_{\text {comp }} / \mathrm{V}_{\mathrm{u}}$ & $\begin{array}{l}\text { Experimental } \\
\text { failure mode }\end{array}$ & Code & $\mathrm{V}_{\text {code }} / \mathrm{V}_{\mathrm{u}}$ & $\begin{array}{c}\text { Normative } \\
\text { failure mode }\end{array}$ \\
\hline \multirow{3}{*}{ L3 } & \multirow{3}{*}{120} & \multirow{3}{*}{150} & \multirow{3}{*}{128} & \multirow{3}{*}{0.47} & \multirow{3}{*}{30.0} & \multirow{3}{*}{617.6} & \multirow{3}{*}{0.96} & \multirow{3}{*}{ PS } & $\mathrm{ACl}$ & 0.31 & SR \\
\hline & & & & & & & & & $\mathrm{EC} 2$ & 0.30 & SR \\
\hline & & & & & & & & & NBR & 0.20 & SR \\
\hline \multirow{3}{*}{ AR2 } & \multirow{3}{*}{200} & \multirow{3}{*}{100} & \multirow{3}{*}{80} & \multirow{3}{*}{1.30} & \multirow{3}{*}{39.1} & \multirow{3}{*}{613.0} & \multirow{3}{*}{1.04} & \multirow{3}{*}{ PS } & $\mathrm{ACl}$ & 0.63 & PS \\
\hline & & & & & & & & & $\mathrm{EC} 2$ & 0.68 & PS \\
\hline & & & & & & & & & NBR & 0.88 & PS \\
\hline
\end{tabular}

PS: Punching shear;

SR: Shear in ribs.

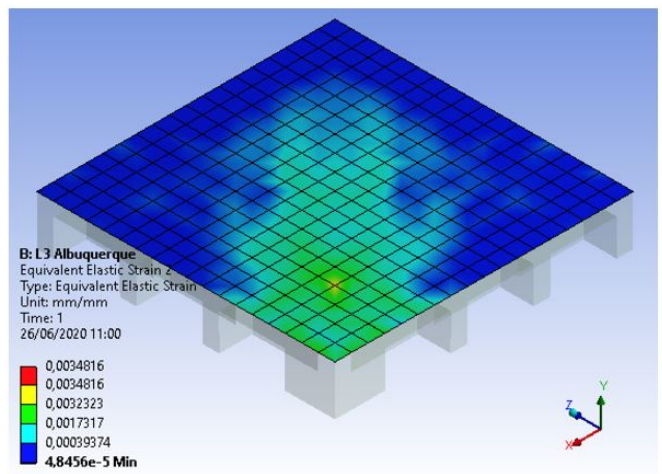

(a) Strains on slab L3 top surface (1/4 of slab)

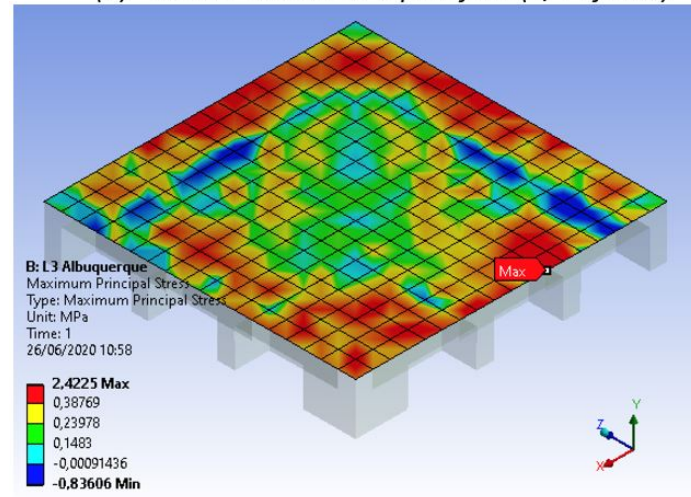

(c) Maximum principal stresses on slab L3 top surface (1/4 of slab)

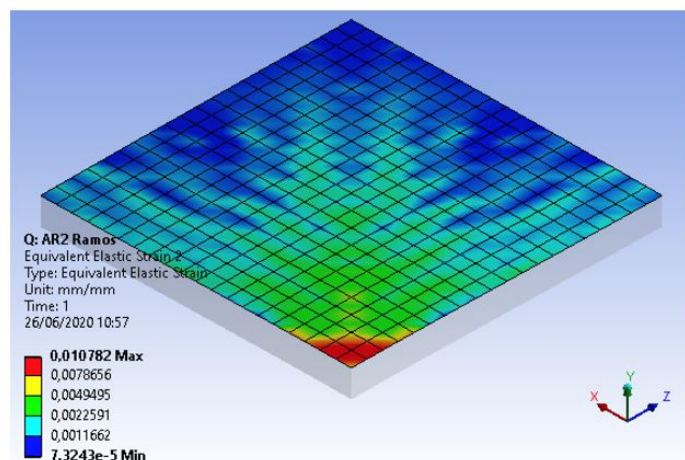

(b) Strains on slab AR2 top surface (1/4 of slab)

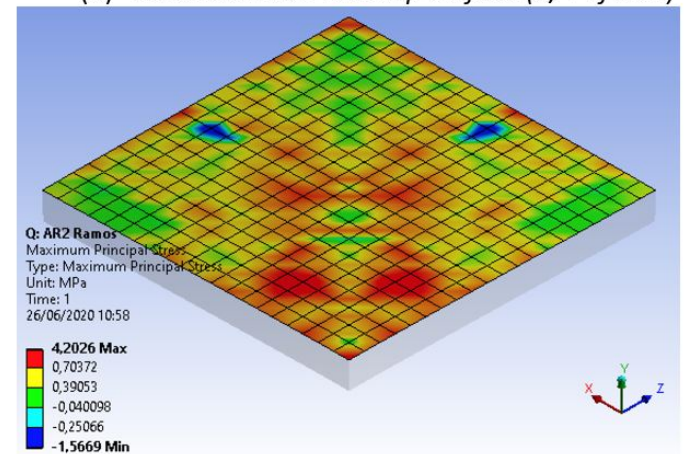

(d) Maximum principal stresses on slab AR2 top surface (1/4 of slab)

Figure 9 - Strains and stresses for slabs (1/4 of slab). Source: Authors' own data

\section{RESULTS AND DISCUSSION}

Table 3 shows the computational and normative results of the study slabs. The computational results show that the solid flat slab, together with the waffle slab with wide beams, were the strongest (groups S0 and S1, respectively) while the waffle flat slab (group S3) was the least resistant. Particularly in the solid flat slab (group SO), the increase in the reinforcement ratio increases slab strength, as expected. For this type of slab, the EC2 estimates were the most similar to the computational results, for the S1SO, S3SO and S4SO slabs. Unsafe results were found, especially for slabs with lower reinforcement ratios. For the waffle slab with wide beams (group S1), it was also found that the increase in the reinforcement ratio increases slab strength. In this case, EC2 estimates were, again, the most similar to the computational results for slabs S1S1, S3S1 and S4S1. There were also unsafe results, especially for slabs with lower reinforcement ratios. For the waffle flat slab with closely spaced ribs (group S2), an increase in the reinforcement ratio also increases slab strength. For this slab system, the $\mathrm{ACl} 318$ estimates were the most similar to the computational results, for the slabs S2S2, S3S2 and S4S2. They were unsafe results for the smallest reinforcement ratios and conservative results for higher reinforcement ratios. For the waffle flat slab (group S3), the increase in the reinforcement ration increases slab strength, in the same way as in the other groups. For this type of slab, the $\mathrm{ACl} 318$ estimates were the ones that came closest to 
the computational results, with the S2S3, S3S3 and S4S3 slabs. Unsafe results were found, especially for slabs with lower reinforcement rates. The NBR6118 estimates for rib shear strength were rather conservative. This code estimated shear failure modes in the ribs (SR) even for the group of slabs with wide beams, for which the other codes and computational modeling had estimated punching shear (PS).

Table 3 Results of computational analyses and normative recommendations

\begin{tabular}{|c|c|c|c|c|c|c|c|c|}
\hline \multirow[b]{2}{*}{ Slab } & \multicolumn{2}{|c|}{ Computational } & \multicolumn{2}{|c|}{$\mathrm{ACl} 318$} & \multicolumn{2}{|c|}{ EC 2} & \multicolumn{2}{|c|}{ NBR 6118} \\
\hline & $\begin{array}{c}\mathbf{V}_{\text {comp }} \\
(\mathrm{kN})\end{array}$ & $\begin{array}{c}\text { failure } \\
\text { mode }\end{array}$ & $\mathrm{V}_{\text {comp }} / \mathrm{V}_{\mathrm{ACl}}$ & $\begin{array}{c}\text { Failure } \\
\text { mode }\end{array}$ & $\mathrm{V}_{\text {comp }} / \mathrm{V}_{\mathrm{EC}}$ & $\begin{array}{c}\text { Failure } \\
\text { mode }\end{array}$ & $\mathrm{V}_{\text {comp }} / \mathrm{V}_{\mathrm{NBR}}$ & $\begin{array}{c}\text { Failure } \\
\text { mode }\end{array}$ \\
\hline S1S0 & 214.7 & PS & 0.76 & PS & 0.79 & PS & 0.71 & PS \\
\hline S2SO & 277.1 & PS & 0.98 & PS & 0.81 & PS & 0.73 & PS \\
\hline S3SO & 330.2 & PS & 1.17 & PS & 0.83 & PS & 0.75 & PS \\
\hline S4SO & 388.3 & PS & 1.38 & PS & 0.87 & PS & 0.79 & PS \\
\hline S1S1 & 200.5 & PS & 1.12 & SR & 0.74 & PS & 0.84 & $S R$ \\
\hline S2S1 & 271.8 & PS & 1.52 & SR & 0.79 & PS & 1.13 & $S R$ \\
\hline S3S1 & 343.3 & PS & 1.92 & SR & 0.87 & PS & 1.43 & $S R$ \\
\hline S4S1 & 367.7 & PS & 2.05 & SR & 0.83 & PS & 1.53 & $S R$ \\
\hline S1S2 & 201.6 & PS & 2.40 & SR & 1.33 & $S R$ & 1.79 & $S R$ \\
\hline S2S2 & 262.3 & PS & 3.12 & SR & 1.38 & SR & 2.33 & SR \\
\hline S3S2 & 309.8 & PS & 3.69 & SR & 1.40 & $S R$ & 2.76 & $S R$ \\
\hline S4S2 & 327.9 & PS & 3.90 & SR & 1.33 & $S R$ & 2.92 & $S R$ \\
\hline S1S3 & 190.4 & PS & 3.78 & SR & 2.10 & $S R$ & 2.83 & SR \\
\hline S2S3 & 230.8 & PS & 4.58 & SR & 2.02 & SR & 3.42 & $S R$ \\
\hline S3S3 & 251.1 & PS & 4.98 & SR & 1.89 & SR & 3.72 & SR \\
\hline \multirow[t]{2}{*}{ S4S3 } & 254.7 & PS & 5.05 & SR & 1.72 & SR & 3.78 & SR \\
\hline & \multicolumn{2}{|c|}{ Median } & 2.62 & & 1.23 & & 1.97 & \\
\hline \multicolumn{3}{|c|}{ Standard Deviation } & 1.43 & & 0.48 & & 1.14 & \\
\hline \multicolumn{3}{|c|}{ Coefficient of Variation (\%) } & 54.58 & & 39.02 & & 57.87 & \\
\hline
\end{tabular}

Figure 10 shows the reference perimeter adopted in this research, which corresponds to a square circumscribed in the control perimeter of EC2 or NBR6118. This reference perimeter was used instead of the traditional control perimeter because it is easier to manually quantify the percentage of the perimeter that contains the slab height (PRh) and the percentage of the perimeter that has only the topping slab height of the waffle slab (PR $)$. The solid flat slab (group SO) and the waffle slab with wide beams (group S1) are the two systems with the highest percentage of PR $\mathrm{R}_{\mathrm{h}}$ coincidentally, they are the two strongest types of slabs, according to computational results found in this research. In comparison, the flat waffle slab (group S3) is the system with the lowest percentage of PR $R_{h}$, coincidentally, it is the least resistant type of slab according to the computational results of this research. In this way, it can be inferred that in different types of slabs, when the reference perimeter $(P R)$ goes beyond the solid region $\left(P R_{h}\right)$, there is a reduction in slab strength. The intention of using slabs with geometry where the reference perimeters (PR) penetrated very little in the area of the ribs was to highlight even more that the estimates of the codes regarding the shear in the ribs (SR) are conservative, as already shown in Table 2. The analyses of the load-displacement curves in Figure 11 show that, as expected, the increase in flexural reinforcement and the higher $\mathrm{PR}_{\mathrm{d}}$ values provided the slabs with greater strength and stiffness. Thus, the slabs S4SO and S4S1 are the stiffest and the strongest slabs, and these characteristics were also found to be present in groups SO and S1. Slab S1S3 was the most flexible and the least resistant. 
Group S0

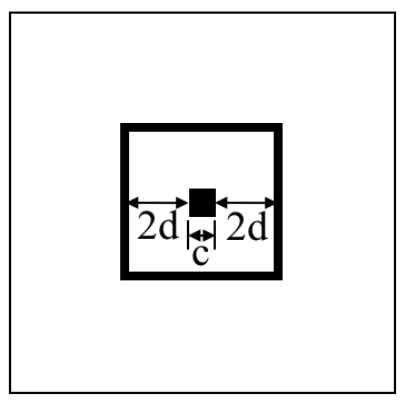

$\mathrm{PR}=4(\mathrm{c}+4 \mathrm{~d})=2614.4 \mathrm{~mm}$ $\mathrm{PR}_{\mathrm{h}}=2614.4 \mathrm{~mm}(100.0 \%)$ $\mathrm{PR}_{\mathrm{t}}=0 \mathrm{~mm}(0.0 \%)$
Group S1

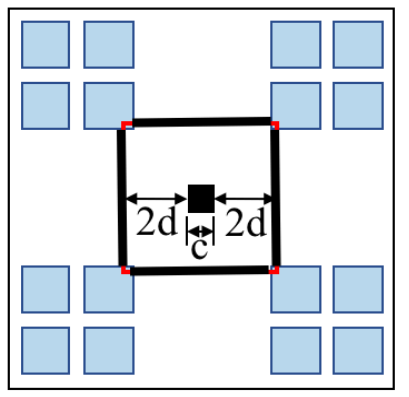

$\mathrm{PR}=4(\mathrm{c}+4 \mathrm{~d})=2614.4 \mathrm{~mm}$ $\mathrm{PR}_{\mathrm{h}}=2560.0 \mathrm{~mm}(97.9 \%)$ $\mathrm{PR}_{\mathrm{t}}=54.4 \mathrm{~mm}(2.1 \%)$
Group S2

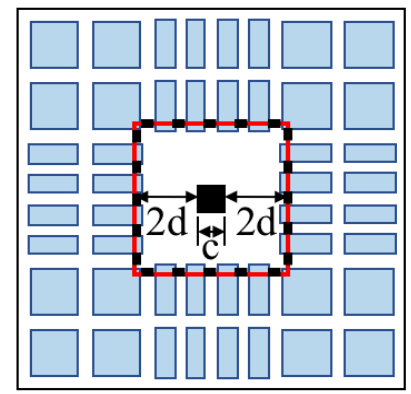

$\mathrm{PR}=4(\mathrm{c}+4 \mathrm{~d})=2614.4 \mathrm{~mm}$ $\mathrm{PR}_{\mathrm{h}}=1200.0 \mathrm{~mm}(45.9 \%)$ $\mathrm{PR}_{\mathrm{t}}=1414.4 \mathrm{~mm}(54.1 \%)$

\section{Group S3}

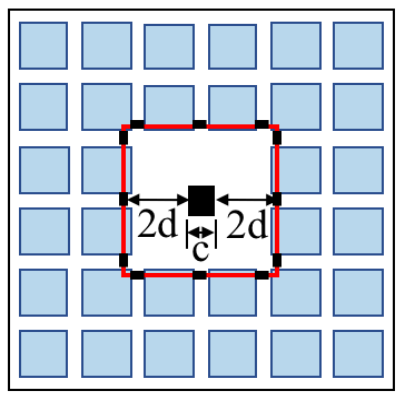

$\mathrm{PR}=4(\mathrm{c}+4 \mathrm{~d})=2614.4 \mathrm{~mm}$ $\mathrm{PR}_{\mathrm{h}}=720 \mathrm{~mm}(27.5 \%)$ $\mathrm{PR}_{\mathrm{t}}=1894.4 \mathrm{~mm}(72.5 \%)$

Figure 10 Reference perimeters (PR). Source: Authors' own data

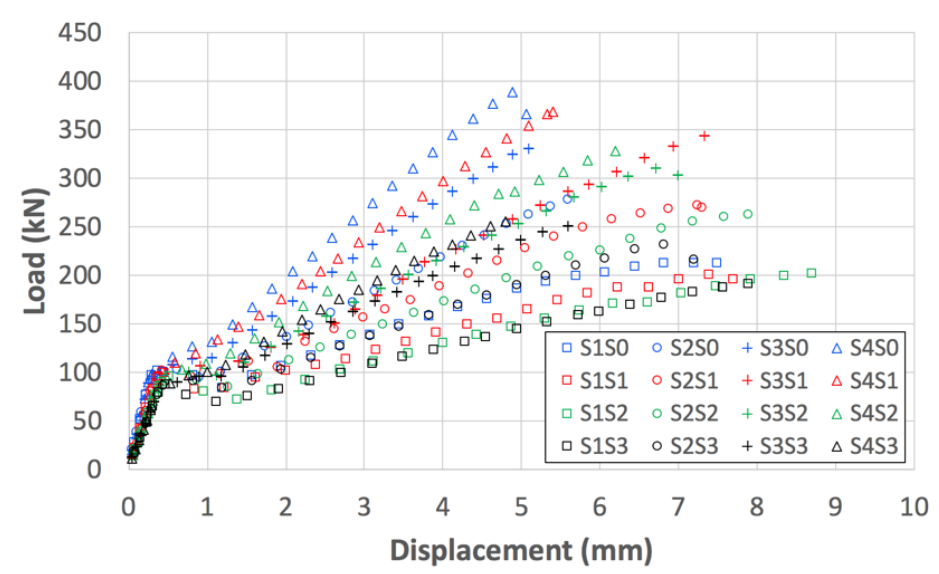

Figure 11 Vertical displacements of the slabs. Source: Authors' own data

Figure 12 shows a comparison of groups S0, S1, S2 and S3 for slabs with the same reinforcement ratio. For slabs of the first, second and fourth blocks, group SO (solid flat slab) was the strongest (slabs S1SO, S2SO, S4SO). For the slabs of the third block, group S1 (waffle slab with wide beams) was the strongest (slab S3S1). For all blocks, group S3 (waffle flat slab) was the weakest. Although the solid flat slabs performed slightly better than the waffle slab with wide beams, it should be noted that the latter has much less concrete volume than the solid flat slab. Had volume been the same, the results of the waffle slab with wide beams would have been better.

Figure 13 shows that slab strength increases when the reinforcement ratio is increased, with the waffle flat slab (group S3) growing on a smaller scale. In this figure, the solid flat slab and the waffle slab with wide beams (groups SO and S1, respectively) were the strongest. In addition, in the graph, 4 equations were added for the linear trend lines that correlate failure load $\left(V_{\text {comp }}\right)$ with the reinforcement ratio $(\rho)$ of the slabs. Figure 14 shows the correlation between failure load $\left(\mathrm{V}_{\text {comp }}\right)$ and slab rotation at failure $(\theta)$. Slab strength decreases with increased slab rotation, and the waffle flat slab (group S3) decreases to a lesser extent than the others. In this figure, the solid flat slab and the waffle slab with wide beams (group S0 and S1, respectively) were the ones that showed the greatest strength. In addition, 4 equations were added to this graph. They are related to the linear trend lines that correlate failure load $\left(V_{\text {comp }}\right)$ with rotation $(\theta)$.

Figure 15 shows the maximum principal (tensile) stresses on the top surface of only two slabs from each group. The red color represents ultimate stress (above $6 \mathrm{MPa}$ for S0 group and above $3 \mathrm{MPa}$ for other groups). The stresses have more red area on the slabs with a lower reinforcement ratio (S1S0, S1S1, S1S2 and S1S3), because the slabs were more flexible and, consequently, higher stress levels. The slabs of group SO were the ones that have less red area in comparison to the others, indicating that the solid flat slab has a better load distribution behavior. Figure 16 shows the minimum principal (compression) stresses on the lower surface of, again, only two of the study slabs while the blue color represents ultimate stress (below -30 MPa for S0 group and below -40 MPa for other groups). The minimum principal stresses (blue and green colors) overlap with the regions of the ribs for groups S2 and S3, while for group S1, they were virtually concentrated in the wide beams. Finally, for the SO group, stresses are distributed in a much more homogeneous manner because the slabs are solid. 


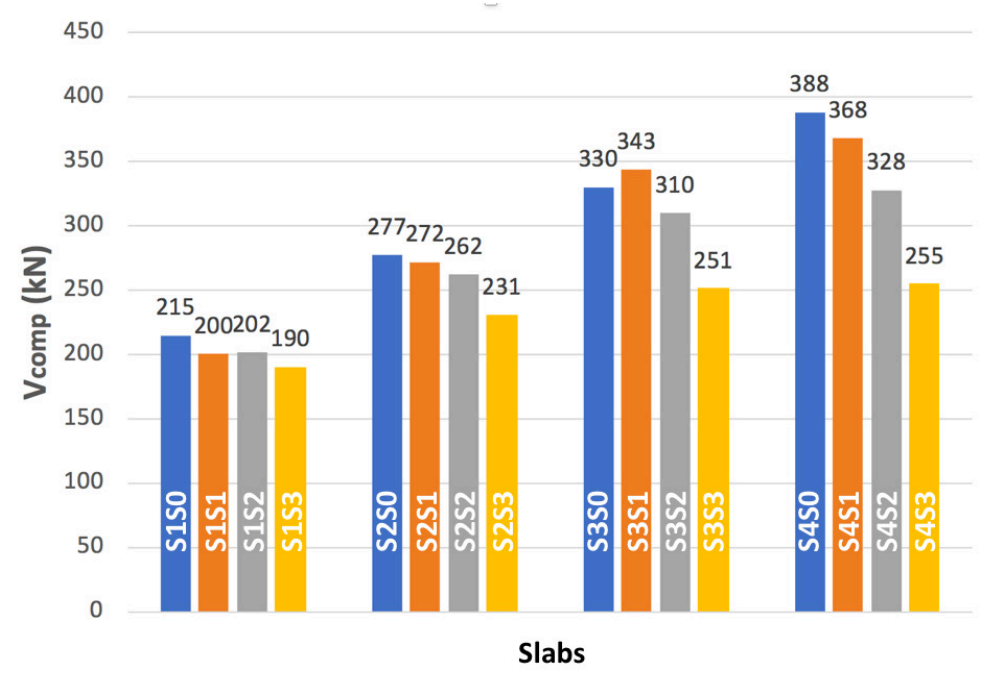

Figure 12 Failure loads of the slabs. Source: Authors' own data

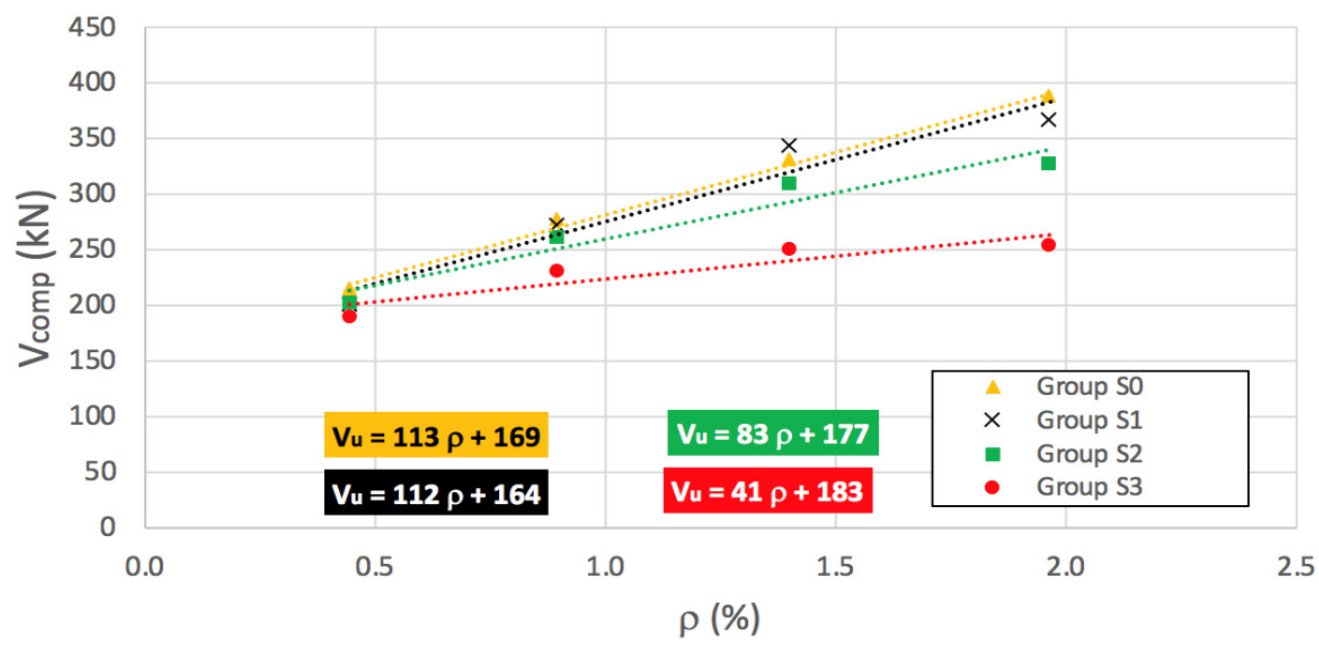

Figure 13 Influence of reinforcement ratio on slab strength. Source: Authors' own data

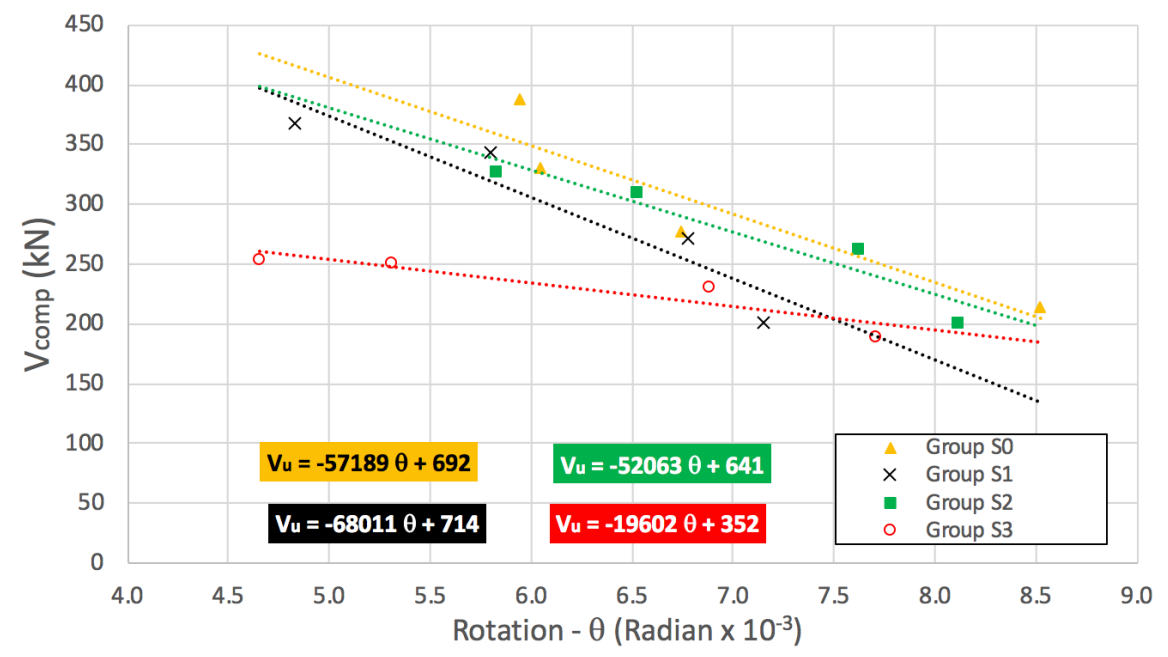

Figure 14 Slab rotation. Source: Authors' own data 


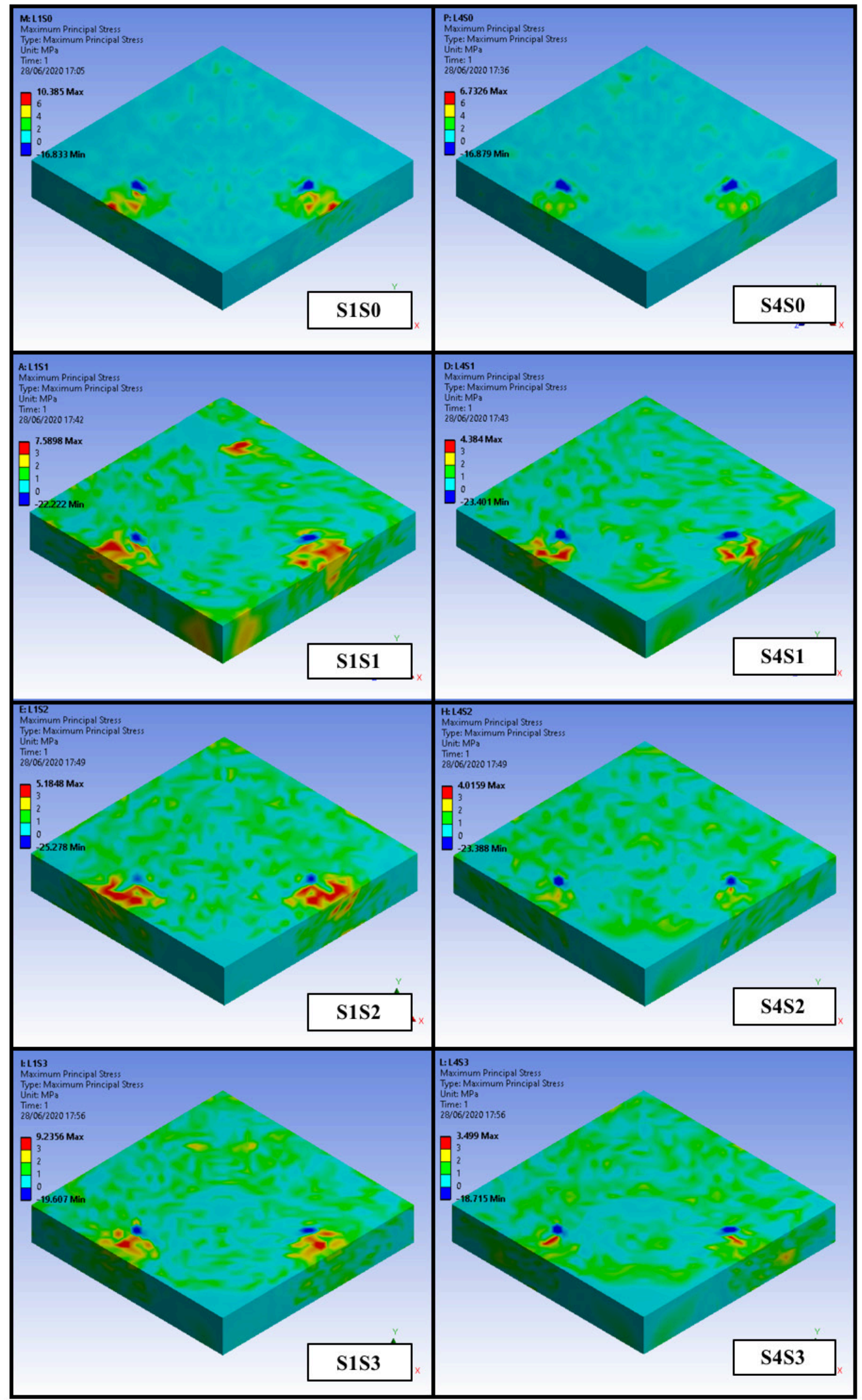

Figure 15 Maximum principal stresses on the top surface of the slabs (1 Quadrant of the slab). Source: Authors' own data 


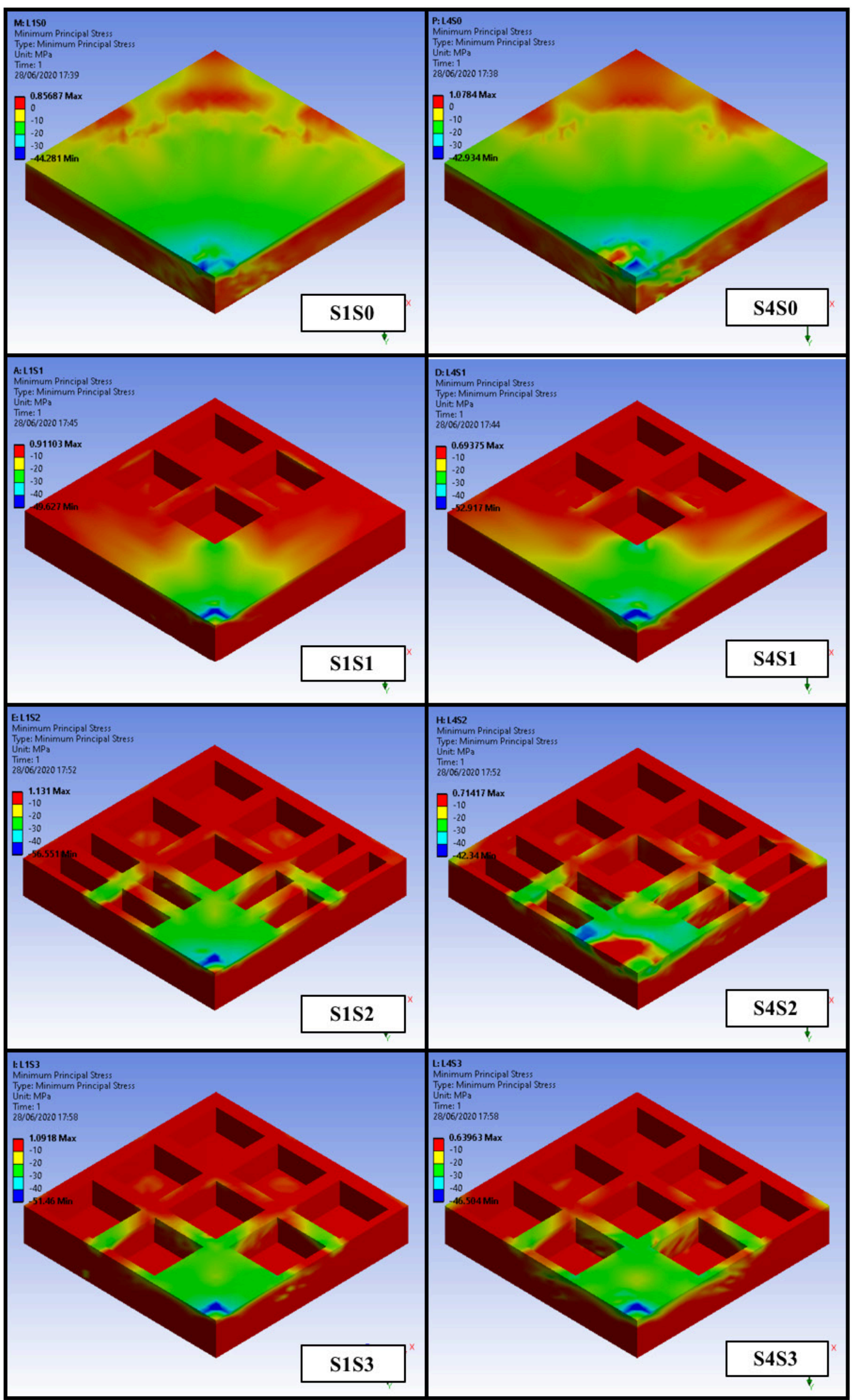

Figure 16 Minimum principal stresses on the bottom surface of the slabs (1 Quadrant of the slab). Source: Authors' own data 


\section{CONCLUSIONS}

This paper presented and discussed theoretical computational results found for 16 solid flat slabs and waffle slabs. It was found that the solid flat slabs (group S0), as well as the waffle slabs with wide beams (group S1), were the strongest, while the waffle flat slabs (group S3) had the worst performance. In general, EC2 was the code that best estimated the failure loads of the slabs, compared to the American and Brazilian codes. However, all codes were extremely conservative when estimating rib strength. For the solid slabs, the American code showed the best results, on average, while the other codes overestimated slab strength. Increasing the reinforcement ratio increased ultimate strength and stiffness of the slabs in the computational models, reducing their rotations. However, further computational and experimental analyses are needed to draw more comprehensive conclusions.

Author Contribuitions: Conceptualization, DRC Oliveira, RJC Silva and NGB Albuquerque; Methodology, RJC Silva, NGB Albuquerque and PVP Sacramento; Software, RJC Silva and FES Silva Júnior; Writing - original draft, RJC Silva, NGB Albuquerque, FES Silva Júnior and PVP Sacramento; Writing - review \& editing, DRC Oliveira; Supervision, DRC Oliveira.

Editor: Marcílio Alves.

\section{References}

Al-Bayati, A. F., Lau, T. L., Clark, L. A. (2015). Concentric punching shear of waffle slab. ACl Structural Journal. v. 112, no 5, pg. 533-542.

Al-Bayati, A. F., Lau, T. L. Clark, L. A. (2018). Eccentric punching shear of waffle slab. ACI Structural Journal. v. 115, no 1, pg. 163-174.

Albuquerque, N. G. B. (2009). Análise experimental de lajes lisas nervuradas de concreto armado com região maciça de geometria variável ao puncionamento. Dissertação de Mestrado. Universidade Federal do Pará, Instituto de Tecnologia, Belém, Pará.

American Concrete Institute - ACl 318M (2019): Building Code Requirements for Structural Concrete and Commentary. Farmington Hills, Michigan.

Ansys (2013a). Ansys Composite PrepPost User's Guide [Manual], Release 15.0. Canosburg, Pensilvania.

Ansys (2013b). Ansys Mechanical APDL Material Reference [Manual], Release 15.0. Canosburg, Pensilvania.

Arunkumar, C., Saketh, K., Senthil, S. S., Jeyashree, T. M. (2018). Behaviour of punching shear in normal RC slab and waffle slab. Asian Journal of Civil Engineering. v. 19, no 1, pg. 27-33.

Bompa, D. V., Onet, T. (2016). Punching shear strength of rc flat slabs at interior connections to columns. Magazine of Concrete Research, v.68, n.01, p.24-42.

Brazilian Association of Technical Standards (ABNT, 2014). NBR 6118: Design of concrete structures - procedure. ABNT, Rio de Janeiro.

European Committee for Standardization (CEN, 2004). Eurocode 2: Design of Concrete Structures - Part 1-1: General Rules and Rules for Buildings. CEN, Brussels.

International Federation for Structural Concrete (FIB, 2011). FIB Model Code for concrete structures 2010. FIB, Lausanne.

Kinnunen, S., Nylander, H. (1960). Punching of Concrete Slabs Without Shear Reinforcement. Transactions of the Royal Institute of Technology, No. 158, Stockholm, Sweden, 112 pp.

Muttoni, A. (2008). Punching Shear Strength of Reinforced Concrete Slabs without Transverse Reinforcement, ACI Structural Journal, V. 105, No. 4, pp. 440-450.

Ramos A.M.P. (2003). Punçoamento em lajes fungiformes pré-esforçadas. Tese de Doutorado. Instituto Superior Técnico, Universidade Técnica de Lisboa, Lisboa, Portugal.

Regan, P. E. (1981). Behavior of reinforced concrete flat slabs. Report 89, Construction Industry Research and Information Association (CIRIA); London, Feb. 1981, p 89. 
Regan, P. E. (1986). Symmetric Punching of Reinforced Concrete Slabs. Magazine of Concrete Research, V. 38, No. 136, pp 115128.

Regan, P. E., Bræstrup, M. W. (1985). Punching Shear in Reinforced Concrete. Comité Euro-International du Béton, Bulletin d)Information, No. 168, 232 pp.

Sacramento, P. V. P., Picanço, M. S., Oliveira, D. R. C. (2018). Lajes nervuradas de concreto armado com viga-faixa. Revista Ibracon de Estruturas e Materiais - RIEM (in Portuguese). v. 11, no 5, 981-996.

Silva, R. J. C., Cabral, A. E. B., Silva Júnior, F. E. S., Vasconcelos Filho, J.L.L., Eugenio, D.E.F. (2019). Analysis of reinforced concrete beams strengthened with different CFRP lengths. Acta Scientiarum. Technology, 42, 1-10.

Willam, K. J., Warnke, E. P. (1974). Constitutive model for the triaxial behaviour of concrete. Proceedings of International Association for Bridge and Structural Engineering, Bergamo, Itália. 